\title{
ANALISIS FITOKIMIA DAN UJI EFEK SEDATIF DARI EKSTRAK ETANOL DAN BEBERAPA FRAKSI DAGING BUAH PALA (Myristica Fragrans Houtt)
}

\author{
Eresia Makanaung ${ }^{1}$, Johnly A. Rorong ${ }^{1}$, Edi Suryanto ${ }^{1}$ \\ Program Studi Kimia Fakultas Matematika dan Ilmu Pengetahuan Alam Universitas Sam Ratulangi Manado \\ Email: eresyam@gmail.com
}

\begin{abstract}
ABSTRAK
Pala adalah tanaman yang termasuk dalam jenis tanaman obat. Penelitian ini bertujuan untuk menganalisis total kandungan fitokimia dan uji efek sedatif dari ekstrak etanol, fraksi petroleum eter, etil asetat dan air daging buah pala. Ekstraksi dilakukan dengan cara maserasi, kemudian ekstrak etanol yang diperoleh difraksinasi dengan cara partisi. Analisis fitokimia dilakukan dengan metode spektrofotometri UV-Vis sehingga diperoleh hasil kandungan total fenolik ekstrak etanol, fraksi petroleum eter, etil asetat dan air daging buah pala secara berturut-turut adalah 26,284 $\mu \mathrm{g} / \mathrm{mL} ; 29,203 \mu \mathrm{g} / \mathrm{mL} ; 28,725 \mu \mathrm{g} / \mathrm{mL} ; 24,904 \mu \mathrm{g} / \mathrm{mL}$. Total flavonoid secara berturut-turut adalah $9,999 \mu \mathrm{g} / \mathrm{mL} ; 13,095 \mu \mathrm{g} / \mathrm{mL} ; 13,729 \mu \mathrm{g} / \mathrm{mL} ; 10,475 \mu \mathrm{g} / \mathrm{mL}$. Total tanin secara berturut-turut adalah 16,642 $\mu \mathrm{g} / \mathrm{mL} ; 16,571 \mu \mathrm{g} / \mathrm{mL} ; 16,357 \mu \mathrm{g} / \mathrm{mL} ; 10,428 \mu \mathrm{g} / \mathrm{mL}$. Uji efek sedatif dilakukan dengan metode traction test dan diperoleh hasil ekstrak etanol dan ketiga fraksi memiliki pengaruh efek sedatif pada dosis 300 $\mathrm{mg} / \mathrm{kgBB}$ dan $500 \mathrm{mg} / \mathrm{kgBB}$ dan dosis yang paling baik dalam memberikan pengaruh efek sedatif adalah 500 $\mathrm{mg} / \mathrm{kgBB}$.
\end{abstract}

Kata kunci: Analisis fitokimia, efek sedatif, daging buah pala

\begin{abstract}
Nutmeg is a plant that is included in a type of medicinal plant. This study aimed to analyze the total phytochemical content and test the sedative effect of ethanol extract, petroleum ether fraction, ethyl acetate and nutmeg pulp. Extraction was carried out by maceration, then the ethanol extract obtained was fractionated by partitioning. Phytochemical analysis was carried out using UV-Vis spectrophotometry method so that the total phenolic content of ethanol extract, petroleum ether fraction, ethyl acetate and nutmeg water was obtained, respectively, $26.284 \mu \mathrm{g} / \mathrm{mL} ; 29,203 \mu \mathrm{g} / \mathrm{mL} ; 28.725 \mu \mathrm{g} / \mathrm{mL} ; 24,904 \mu \mathrm{g} / \mathrm{mL}$. The total flavonoids were $9.999 \mu \mathrm{g} / \mathrm{mL}$, respectively; $13.095 \mu \mathrm{g} / \mathrm{mL} ; 13,729 \mu \mathrm{g} / \mathrm{mL} ; 10,475 \mu \mathrm{g} / \mathrm{mL}$. The total tannins were $16,642 \mu \mathrm{g} / \mathrm{mL}$, respectively; $16,571 \mu \mathrm{g} / \mathrm{mL} ; 16,357 \mu \mathrm{g} / \mathrm{mL} ; 10,428 \mu \mathrm{g} / \mathrm{mL}$. The sedative effect test was carried out by the traction test method and the results of the ethanol extract and the three fractions had a sedative effect at a dose of $300 \mathrm{mg} / \mathrm{kgBB}$ and $500 \mathrm{mg} / \mathrm{kgBB}$ and the best dose in giving a sedative effect was $500 \mathrm{mg} / \mathrm{kgBB}$.
\end{abstract}

Key words: Phytochemical analysis, sedative effect, nutmeg pulp

\section{PENDAHULUAN}

Indonesia memiliki jenis tanaman obat yang banyak ragamnya. Jenis tanaman yang termasuk dalam kelompok tanaman obat mencapai lebih dari 1000 jenis, salah satunya yaitu buah pala (Myristica fragrans Houtt). Buah pala dikenal sebagai tanaman rempah-rempah yang memiliki nilai ekonomis dan multiguna karena setiap bagian tanaman dapat dimanfaatkan dalam berbagai industri makanan, minuman, obat-obatan, parfum dan kosmetik (Nurdjannah, 2007).
Berdasarkan penelitian sebelumnya, ekstrak biji pala (Myristica fragrans Houtt) dengan dosis 7,5 $\mathrm{mg} / 25 \mathrm{~g} \quad \mathrm{BB}$ dapat memperpendek waktu induksi tidur dan dapat memperpanjang lama waktu tidur mencit yang diinduksi thiopental secara signifikan (Rahadian, 2009). Daging buah pala mengandung zat aromatik flavour yang terdiri dari minyak atsiri yaitu miristisin dan monoterpen (Jaiswal dkk. 2009; Nagja dkk., 2016).

Kandungan miristisin yang terdapat dalam minyak pala dapat digunakan sebagai 
obat bius dan campuran obat-obatan tertentu (Friyadi, 2002). Ekstrak etanol daging buah, fuli dan biji pala memiliki kandungan senyawa alkaloid, saponin, tanin, flavonoid dan terpenoid (Atmaja dkk., 2017). Hasil uji fitokimia yang dilakukan oleh Thomas \& Krishnakumari (2015) menyatakan bahwa analisis kualitatif dari ekstrak biji pala mengkonfirmasikan adanya metabolit sekunder seperti alkaloid, flavonoid, saponin, tanin, fenol dan terpenoid. Kandungan saponin, flavonoid dan tanin dilaporkan dapat menyebabkan efek sedatif (Takahashi dkk., 1986; Hanrahan dkk., 2011; Srivastava dkk. 2010; Asgharzade dkk. 2015). Efek sedatif juga dilaporkan berasal dari kandungan fenolik (Nugroho dkk., 2012).

Sedatif merupakan substansi yang memiliki aktifitas yang memberikan efek menenangkan, obat yang mengurangi gejala cemas, dengan sedikit atau tanpa efek terhadap status mental atau motorik. Obat-obatan hipnotik sedatif adalah istilah untuk obat-obatan yang mampu mendepresi sistem saraf pusat dan mampu memberikan efek terhadap penderita insomnia (Tjay dkk., 2002). Insomnia adalah ketidakmampuan untuk memulai tidur atau sulit mempertahankan keadaan tidur. Salah satu cara untuk mengatasi insomnia adalah menggunakan obat-obat golongan hipnotik sedatif, akan tetapi banyak diantara obat tersebut yang dilaporkan bersifat toksik bahkan menyebabkan kematian (Roth, 2007). Tujuan penelitian ini adalah untuk menentukan kandungan fitokimia dan mengevaluasi efek sedatif dari daging buah pala terhadap tikus putih.

\section{BAHAN DAN METODE}

Daging buah pala diperoleh dari Minahasa. Bahan yang digunakan adalah etanol, natrium hidroksida, kalium asetat, petroleum eter, etil asetat, reagen Folin-Ciocalteu, reagen Denis, aluminum klorida dan natrium karbonat diperoleh dari Merck (Damstadt, Germany). Asam galat, kuersetin dan katekin diperoleh dari Sigma-Aldrich

\section{Preparasi sampel}

Sampel yang digunakan dalam penelitian ini adalah daging buah pala. Sampel tersebut dikering anginkan selama 1 minggu, dimasukkan ke dalam oven pada suhu $40{ }^{\circ} \mathrm{C}$ selama 24 jam, diblender hingga berbentuk serbuk dan diayak menggunakan ayakan 65 mesh.

\section{Ekstraksi dan fraksinasi}

Serbuk daging buah pala sebanyak $250 \mathrm{~g}$ dimaserasi dengan etanol $1000 \mathrm{~mL}$ selama 24 jam. Selanjutnya disaring, diperoleh filtrat dan residu. Proses ini dilakukan tiga kali pengulangan. Ketiga filtrat digabungkan, dievaporasi menggunakan rotary evaporator. Sebanyak $10 \mathrm{~g}$ ekstrak dilarutkan dalam $100 \mathrm{~mL}$ aquades, kemudian larutan dipartisi dengan menambahkan $100 \mathrm{~mL}$ petroleum eter dan dikocok dalam corong pisah hingga terdapat dua lapisan (aquades pada lapisan bawah dan petroleum eter pada lapisan atas). Diambil lapisan petroleum eter, dilakukan beberapa kali sampai lapisan petroleum eter terlihat bening. Lapisan aquades kemudian dipartisi kembali dengan cara yang sama menggunakan pelarut etil asetat dan air sehingga diperoleh fraksi petroleum eter, fraksi etil asetat dan fraksi air, kemudian diuapkan pelarutnya menggunakan rotary evaporator.

\section{Penentuan kandungan total fenolik}

Kandungan total fenolik ekstrak etanol, fraksi petroleum eter, fraksi etil asetat dan fraksi air ditentukan menggunakan uji Folin Ciocalteu (Conde dkk., 1997). Sebanyak 0,1 mL ekstrak dimasukkan ke dalam tabung reaksi lalu ditambahkan reagen $0,25 \mathrm{~mL}$ Folin Ciocalteu $50 \%$. Campuran antara ekstrak dan reagen divortex dan ditambahkan $1 \mathrm{~mL}$ larutan natrium karbonat 2\%. Campuran diinkubasi dalam ruang gelap selama 30 menit. Absorbansinya dibaca pada panjang gelombang $750 \mathrm{~nm}$ dengan instrumen spektrofotometer UV-Vis. Hasil diplotkan menggunakan standard kuersetin yang dibuat dengan menggunakan cara yang sama.

\section{Penentuan kandungan total flavonoid}

Kandungan total flavonoid ekstrak etanol, fraksi petroleum eter, fraksi etil asetat dan fraksi air ditentukan menggunakan metode Chang dkk. (2002). Sebanyak $1 \mathrm{~mL}$ ekstrak ditambahkan $3 \mathrm{~mL}$ etanol, ditambahkan juga 0,2 $\mathrm{mL}$ aluminium klorida $10 \%$ dan $0,2 \mathrm{~mL}$ kalium asetat. campuran diinkubasi selama 30 menit dalam ruang gelap pada suhu kamar, 
absorbansinya diukur pada spektrofotometer UVVis dengan panjang gelombang $433 \mathrm{~nm}$. Hasil diplotkan menggunakan standard kuersetin yang dibuat dengan menggunakan cara yang sama.

\section{Penentuan kandungan total tanin}

Kandungan total tanin ekstrak etanol, fraksi petroleum eter, fraksi etil asetat dan fraksi air ditentukan menggunakan metode Mukhriani dkk. (2014). Sebanyak $1 \mathrm{~mL}$ ekstrak dimasukkan ke dalam wadah berukuran $10 \mathrm{~mL}$ yang telah berisi $6,5 \mathrm{~mL}$ akuades. Ditambahkan $2,5 \mathrm{~mL}$ pereaksi Folin Denis, didiamkan selama 3 menit, ditambahkan $1 \mathrm{~mL}$ natrium karbonat jenuh. Diinkubasi selama 15 menit, absorbansinya diukur pada spektrofotometer UV-Vis dengan panjang gelombang $740 \mathrm{~nm}$. Hasil diplotkan menggunakan standard tanin (katekin) yang dibuat dengan menggunakan cara yang sama.

\section{Uji efek sedatif (Alnamer dkk., 2012)}

Parameter yang diamati adalah
penurunan aktivitas motorik dengan
menggunakan metode traction test yaitu
lengan/tungkai paling depan hewan uji
digantungkan pada suatu kawat yang telah
diregangkan secara horizontal. Hewan normal
setelah digantungkan pada kawat akan memiliki

waktu jatuh dari alat traction test yang lama dan akan segera membalikkan badannya kembali agar posisi badannya tetap seimbang (negatif). Sedangkan tikus yang terpengaruh efek sedatif akan segera jatuh dari alat traction test dan membutuhkan waktu lama untuk mengkondisikan tubuhnya kembali agar tetap seimbang. Hal ini menunjukkan bahwa tikus berada dalam pengaruh efek sedatif (positif).

\section{HASIL DAN PEMBAHASAN}

\section{Ekstraksi dan fraksinasi}

Hasil maserasi $250 \mathrm{~g}$ serbuk daging buah pala dengan pelarut etanol adalah 25,9 g ekstrak kental. Sebanyak $10 \mathrm{~g}$ ekstrak etanol kemudian difraksinasi dengan cara partisi. Fraksinasi dilakukan dengan berbagai pelarut yang memiliki tingkat kepolaran yang berbeda mulai dari pelarut nonpolar, semi polar sampai yang polar. Senyawa-senyawa yang bersifat polar akan larut dalam pelarut polar sedangkan senyawasenyawa nonpolar akan larut dalam pelarut nonpolar. Pelarut yang digunakan yaitu petroleum eter, etil asetat dan air sehingga diperoleh hasil seperti pada tabel 1.

Tabel 1. Hasil partisi ekstrak etanol daging buah pala

\begin{tabular}{lcc}
\hline Hasil partisi & Massa $(\mathrm{g})$ & Rendemen (\%) \\
\hline Fraksi air & 3,98 & 39,8 \\
Fraksi petroleum eter & 2,75 & 27,5 \\
Fraksi etil asetat & 2,13 & 21,3 \\
\hline
\end{tabular}

\section{Total kandungan fitokimia}

Penentuan kadar fenolik total menggunakan uji Folin Ciocalteu (Conde dkk., 1997). Pada pengukuran absorbansi fenolik total untuk penentuan kurva standar asam galat dengan panjang gelombang $750 \mathrm{~nm}$ didapat persamaan regresi $y=0,0942 x+0,0129$ dengan nilai koefisien determinasi sebesar 0,09799. Konsentrasi total fenolik dalam ekstrak ditentukan berdasarkan kemampuan senyawa fenolik dalam daging buah pala yang bereaksi dengan asam fosfomolibdat-fosfotungstat dalam reagen Folin Ciocalteu yang menghasilkan senyawa kompleks yaitu molibdenum-tungstat dengan perubahan warna menjadi biru. Jika warna biru yang dihasilkan semakin pekat setelah penambahan reagen menunjukkan semakin besar konsentrasi total senyawa fenolik pada tanaman (Julkunen-Tiito, 1985).

Penentuan kadar flavonoid total menggunakan metode Chang dkk. (2002). Pada pengukuran absorbansi flavonoid total untuk penentuan kurva standar kuersetin dengan panjang gelombang $433 \mathrm{~nm}$ didapat persamaan regresi $y=0,063 x+0,012$ dengan nilai koefisien determinasi sebesar 0.990. Prinsip dari metode $\mathrm{AlCl}_{3}$ yaitu pembentukan kompleks yang stabil dengan C-4 gugus keto, serta pada C-3 atau C-5 gugus hidroksil dari flavon dan flavonol (Cahyanta, 2016). 
Tabel 2. Hasil analisis kandungan fitokimia

\begin{tabular}{lccc}
\hline \multirow{2}{*}{ Ekstrak dan fraksi } & \multicolumn{3}{c}{ Kandungan fitokimia $(\mu \mathrm{g} / \mathrm{mL})$} \\
\cline { 2 - 4 } & Fenolik & Flavonoid & Tanin \\
\hline Ekstrak etanol (EE) & 26,284 & 9,99 & 16,64 \\
Fraksi petroleum eter (FPE) & 29,203 & 13,09 & 16,57 \\
Fraksi etil asetat (EA) & 28,725 & 13,73 & 16,36 \\
Fraksi air (FA) & 24,904 & 10,48 & 10,43 \\
\hline
\end{tabular}

Penentuan kadar tanin total menggunakan metode Mukhriani dkk. (2014). Pada pengukuran absorbansi tanin total untuk penentuan kurva standar asam tanat dengan panjang gelombang $740 \mathrm{~nm}$ didapat persamaan regresi $\mathrm{y}=0,007 \mathrm{x}+0,096$ dengan nilai koefisien determinasi sebesar 0,979 . Nilai $\left(R^{2}\right)$ yang mendekati satu menunjukkan bahwa persamaan regresi tersebut adalah linear. Pada penelitian ini kandungan tanin total ditentukan berdasarkan penambahan reagen pembentuk warna, yaitu folin denis. Pembentukan warnanya berdasarkan reaksi reduksi oksidasi, dimana tanin sebagai reduktor dan folin denis sebagai oksidator. Prinsip dari metode folin denis adalah terbentuknya senyawa kompleks berwarna biru yang dapat diukur serapannya pada daerah sinar tampak.

\section{Pengujian efek sedatif}

Pada pengujian efek sedatif ini ada dua pengamatan yang dilakukan yaitu pengamatan secara kualitatif berupa waktu balik badan hewan uji yaitu tikus ketika tungkai bagian depan tikus digantungkan ke kawat pada alat traction test maka dilihat reaksi balik badan terjadi apabila tungkai tikus bagian bawah dapat mencapai kawat. Semakin lama waktu yang diperlukan tikus agar tungkai bagian bawah mencapai kawat sebelum akhirnya terjatuh maka dapat dinyatakan bahwa tikus tersebut berada dalam pengaruh efek sedatif dan waktu balik badan dicatat. Pengamatan secara kuantitatif berupa waktu yang diperlukan tikus untuk jatuh dari alat traction test semakin cepat waktu yang diperlukan tikus untuk jatuh maka dapat dinyatakan tikus berada dibawah pengaruh efek sedatif (Alnamer dkk., 2012).

Tabel 3. Hasil refleks balik badan tikus

\begin{tabular}{|c|c|c|c|c|c|c|}
\hline \multirow{2}{*}{ Kelompok uji } & \multicolumn{6}{|c|}{ Refleks balik badan tikus (detik) } \\
\hline & 0 & 5 & 10 & 15 & 20 & 25 \\
\hline Kontrol (-) & ada & ada & ada & ada & ada & $\mathrm{x}$ \\
\hline Kontrol $(+)$ & $\mathrm{x}$ & $\mathrm{x}$ & $\mathrm{x}$ & $\mathrm{x}$ & $\mathrm{x}$ & $\mathrm{x}$ \\
\hline Ekstrak etanol (EE) 300 & $\mathrm{x}$ & ada & ada & ada & $\mathrm{x}$ & $\mathrm{x}$ \\
\hline Fraksi petroleum eter (FPE) 300 & $\mathrm{x}$ & ada & ada & $\mathrm{x}$ & $\mathrm{x}$ & $\mathrm{x}$ \\
\hline Fraksi etil asetat (EA) 300 & $\mathrm{x}$ & $\mathrm{x}$ & ada & ada & $\mathrm{x}$ & $\mathrm{x}$ \\
\hline Fraksi air (FA) 300 & $\mathrm{x}$ & $\mathrm{x}$ & ada & ada & $\mathrm{x}$ & $\mathrm{x}$ \\
\hline Ekstrak etanol (EE) 500 & $\mathrm{x}$ & ada & ada & $\mathrm{x}$ & $\mathrm{x}$ & $\mathrm{x}$ \\
\hline Fraksi petroleum eter (FPE) 500 & $\mathrm{x}$ & ada & $\mathrm{x}$ & $\mathrm{x}$ & $\mathrm{x}$ & $\mathrm{x}$ \\
\hline Fraksi etil asetat (EA) 500 & $\mathrm{x}$ & ada & $\mathrm{x}$ & $\mathrm{x}$ & $\mathrm{x}$ & $\mathrm{x}$ \\
\hline Fraksi air (FA) 500 & $\mathrm{x}$ & ada & ada & $\mathrm{x}$ & $\mathrm{x}$ & $\mathrm{x}$ \\
\hline
\end{tabular}


Data kualitatif berupa refleks balik badan yang diperoleh dari hasil penelitian menunjukkan adanya penurunan aktivitas. Pada kelompok kontrol negatif tidak terdapat penurunan aktivitas karena hingga detik ke-20 tikus masih menunjukkan refleks balik badan sebelum akhirnya terjatuh. Sementara itu pada kelompok uji lainnya tikus tidak memiliki waktu yang lama untuk tetap mempertahankan keseimbangan dengan mengangkat tungkai bagian bawah untuk mencapai kawat karena beberapa saat kemudian langsung terjatuh. Hal ini menunjukkan bahwa kelompok positif, ekstrak etanol, fraksi petroleum eter, fraksi etil asetat dan fraksi air mengalami penurunan aktivitas. Selanjutnya untuk hasil pengamatan secara kuantitatif terdapat perbedaan waktu jatuh kontrol positif dengan kontrol negatif dan masing-masing dosis larutan uji. Hewan uji dibawah pengaruh diazepam sebagai kontrol positif memiliki waktu jatuh yang rendah artinya hewan uji memerlukan waktu yang lebih cepat untuk jatuh, kemudian diikuti oleh fraksi petroleum eter, ekstrak etanol, fraksi etil asetat dan fraksi air. Kontrol negatif memiliki waktu jatuh yang lebih tinggi. Hal ini menunjukkan bahwa hewan uji normal karena hewan uji yang normal akan memiliki waktu yang cukup lama untuk bisa jatuh dari kawat.

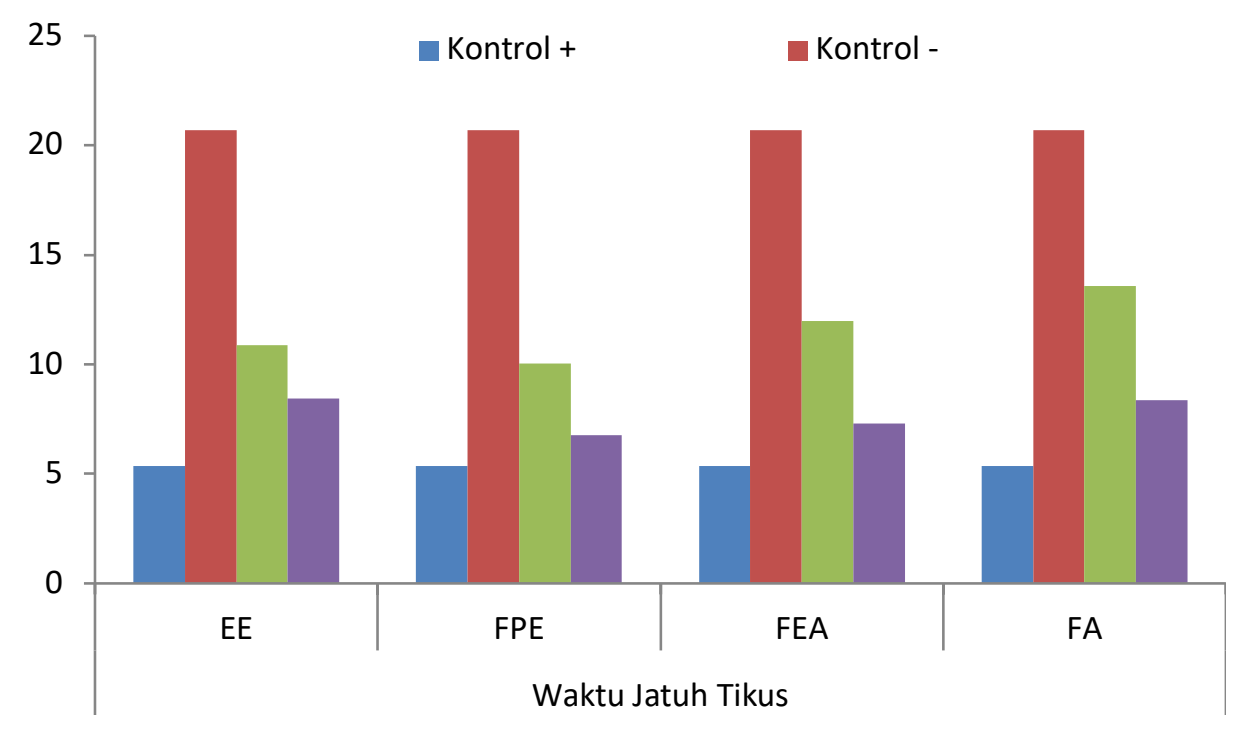

Gambar 1. Waktu jatuh tikus

Dari hasil yang diperoleh dapat dilihat bahwa kontrol positif memiliki perbedaan yang signifikan dengan ekstrak etanol (EE), fraksi petroleum eter (FPE), fraksi etil asetat (FEA) dan fraksi air (FA) pada dosis $300 \mathrm{mg} / \mathrm{Kg}$ BB dengan nilai signifikansi secara berturut-turut 0,032 ; 0,044; 0,022 dan 0,020. Sedangkan pada dosis $500 \mathrm{mg} / \mathrm{KgBB}$ tidak terdapat perbedaan yang signifikan karena memiliki nilai signifikansi lebih dari 0,05 yaitu 0,$188 ; 0,499 ; 0,435$ dan 0,322 . Selanjutnya jika kontrol negatif dibandingkan dengan kontrol positif, ekstrak etanol dan ketiga fraksi dengan dosis 300 dan $500 \mathrm{mg} / \mathrm{Kg} \mathrm{BB}$ memiliki perbedaan yang signifikan.

\section{KESIMPULAN}

Total kandungan fitokimia pada daging buah pala yang paling tinggi terdapat pada fraksi petroleum eter dengan nilai untuk total kandungan fenolik sebesar $29,203 \mu \mathrm{g} / \mathrm{mL}$, total kandungan flavonoid sebesar $13,095 \mu \mathrm{g} / \mathrm{mL}$ dan total kandungan tannin sebesar $16,571 \mu \mathrm{g} / \mathrm{mL}$. Untuk hasil pengujian efek sedatif adalah ekstrak etanol, fraksi petroleum eter, fraksi etil asetat dan fraksi air memiliki pengaruh efek sedatif yang paling efektif memberikan efek sedatif adalah dosis $500 \mathrm{mg} / \mathrm{Kg}$ BB. 


\section{DAFTAR PUSTAKA}

Agaus, L. R \& Agaus, R.V. 2019. Manfaat kesehatan tanaman pala (Myristica fragrans). Medula. 6(3), 662-666.

Asgharzade. S., Rabiei, Z. \& Kopaei, M.R 2015. Effect of Marticaria chamomilla extract on motor coordination impairment indiced by scopolamine in Rats. Asian Pasific Journal of Biomedicenes. 5(10), 829-833.

Alnamer. R., Alaoui. K., Bouidida. E.H., Benjouad. A. \& Cherrah. Y. 2012. Sedatif \& hypnotic activities of the methanolic \& aqueous extracts of Lavandula officinalis from Morocco. Advances in Pharmacological Sciences. 1(5), 1-5.

Atmaja, W.H.T., Mudatsir \& Samingan. 2017. Pengaruh konsentrasi ekstrak etanol buah pala (Myristica Fragrans) terhadap daya hambat Staphylococcus aureus. Jurnal Edubio Tropika. 5(1), 1-53.

Cahyanta, A.N. 2016. Penetapan kadar flavonoid total ekstrak daun pare metode kompleks kolorimetri dengan pengukuran absorbansi secara spektrofotometri. Jurnal Para Pemikir. 5(1), 58-61.

Chang, C., Yang, M., Wen, H. \& Chern, J. 2002. Estimation of total flavonoid content in propolis by twocomplementary colorimetric methods. Journal of Food and Drug Analisis, 10(3), 178-182.

Conde, E., E. Cadahia, M. C Garcia-Vallejo, B.F.D. Simon \& J.R.G Adradros. 1997. Low Molecular Weight Polyphenol in Cork of Qoercus Suber. Journal Agricultural and Food Chemistry. 45(7), 2695-2700.

Friyadi, A. 2002. Isolasi miristisin dari minyak pada (Myristicin fragrans) dengan metode penyulingan uap. Thesis. Agroindustrial Technology IPB. Harus jurnal cek

Hanraham, J.R., Chebib, M. \& Johnston, G.A. R. 2011. Flavonoid modulation of GABAA receptors. British Journal of Pharmacology. 163(2), 234-35.

Jaiswal, P., Kumar, P., V.K. \& Singh, D.K. 2009. Biological effects of Myristica fragrans. Annual Review Biomedical Science. 11():21-29.
Julkunen-Tiitto, R. 1985. Phenolics consituents in the leaves of nothern willows: methods for the analysis of certain phenolics. Journal Agricultural and Food Chemistry. 33(2), 213-217.

Mukhriani, Faridha, Y.N \& Mumang. 2014. Penetapan kadar tanin total ekstrak biji jintan hitam (Nigella sativa) secara spektrofotometri UV-Vis. Jurnal Farmasi. 2(4), 154-158.

Nagja, T., Vimal, K. \& Sanjeev, A. 2016. Myristica fragrans: A comprehensive review. International Journal of Pharmacy and Pharmaceutical Sciences. 8(2), 27-30.

Nurdjannah, N. 2007. Teknologi Pengolahan Pala. Badan Penelitian dan Pengembangan Pertanian: Bogor.

Rahadian, D. D. 2009. pengaruh ekstrak biji pala (Myristica fragrans Houtt) dosis 7,5 $\mathrm{mg} / 25 \mathrm{~g}$ BB terhadap waktu induksi tidur dan lama waktu tidur mencit balb/c yang diinduksi Thiopental. Karya Tulis Ilmiah. Fakultas Kedokteran Universitas Diponegoro: Semarang.

Nugroho, A., Kim, M_H. \& Park, H-J. 2012. Phytochemical studies of the phenolic substances in Aster glehni extract and its sedative and anticonvulsant activity. Archives of Pharmacal Research. 35(3), 423-430

Rorong, J. \& Suryanto, E. 2010. Analisis fitokimia enceng gondok (Eichhornia crassipes) dan efeknya sebagai agen photoreduksi $\mathrm{Fe}^{3+}$. Chemistry Progress. 13(1), 33-41.

Roth, T. 2007. Insomnia: Definition, prevelence, etiology, \& consequences. sleep disorder $\&$ research center, Henry Ford Hospital Detroit. Journal of Clinical Sleep Medicine. 3(5), 7-10.

Srivastava, J.K., Shankar, E. \& Gupta, S. 2010. Chamomile: A herbal medicine of the past with a bright future (Review). Molecular Medicine Report. 3(6 ), 895901.

Suryanto, E. 2012. Fitokimia Antioksidan. Putra Media Nusantara: Surabaya.

Takahashi, R.N., de Lima, T. C \& Morato, G.S. 1986. Pharmacological actions of tannic acid; II. evaluation of cns activity in 
animals. Planta Medica. 52(04), 272- Tjay \& Rahardja, 2002. Obat-obat Penting, 275.

Thomas, R.A \& Krishnakumari, S. 2015. Phytochemical profiling of myristica fragrans seed extract with different organic solvents. Asian Journal of Pharmaceutical And Clinical Research. Khasiat, Pengunaaan dan Efek Sampingnya, Edisi V. PT Elex Media Komputindo Kelompok Gramedia: Jakarta. 8(1), 303-307. 